\title{
Effects of bison grazing, fire, and topography on floristic diversity in tallgrass prairie
}

\author{
DAVID C. HARTNETT, KAREN R. HICKMAN AND LAURA E. FISCHER WALTER
}

\author{
Authors are professor and graduate research assistants, Division of Biology and Kansas Agricultural Experiment \\ Station, Kansas State University, Manhattan, Kan. 66506
}

\begin{abstract}
Grazed and ungrazed sites subjected to different fire frequencies were sampled on the Konza Prairie Research Natural Area in northeast Kansas after 4 years of bison grazing (1987-1991). The objective was to study effects of bison grazing on plant species composition and diversity components (plant species richness, equitability, and spatial heterogeneity) in sites of contrasting fire frequency. Cover and frequency of cool-season graminoids (e.g. Poa pratensis L., Agropyron smithii Rydb., Carex spp.) and some forbs (e.g. Aster ericoides [A. Gray] Howell, and Oxalis stricta $\mathrm{L}$.) were consistently higher in sites grazed by bison than in ungrazed exclosures, whereas the dominant warm-season grasses (Andropogon gerardii Vitman, Sorghastrum nutans [L.] Nash, Panicum virgatum L., Schizachyrium scoparium [Michx.] Nash) and other forbs (e.g. Solidago missouriensis Nutt.) decreased in response to bison. Plant species diversity $\left(\mathrm{H}^{\prime}\right)$ and spatial heterogeneity in all areas sampled were significantly increased by bison. Increased heterogeneity and mean species richness in grazed prairie ( 40 species per sample site) compared to ungrazed prairie (29 species per site) were likely a result of greater microsite diversity generated by bison, whereas preferential grazing of the dominant grasses and concomitant increases in subordinate species resulted in an increase in equitability of species abundances. Species/area relationships indicated greater effects of bison on plant species richness with increasing sample area. Increases in plant diversity components associated with bison grazing were generally greater in annually burned than in 4-year burned sites. Effects of ungulate grazers on floristic diversity have important implications given recent evidence that plant species diversity and the compositional and production stability of grassland plant communities are positively related.
\end{abstract}

Key Words: biodiversity, plant communities, species diversity

In North America tallgrass prairie, large ungulate grazers and periodic fire historically have had major roles in shaping plant community structure and the evolution of its component species (Axelrod 1985, Dyksterhuis 1958, Risser et al. 1981, Weaver 1968). Although effects of fire and cattle grazing have been examined (Collins 1987, Collins and Wallace 1990, Gibson and

\footnotetext{
This research was supported by NSF grant BSR-8906475 to D. Hartnett and NSF grant BSR-8514327 for Long-Term Ecological Research on Konza Prairie. Contribution 95-196-J of the Kansas Agricultural Experiment Station. We appreciate discussions and numerous constructive comments by A.K. Knapp, C.E. Owensby, S.L. Collins and A.A. Steuter.

Manuscript accepted 3 December 1994.
}

Hulbert 1987, Herbal and Anderson 1959, Kucera 1956), the influence of native grazers on tallgrass prairie plant community structure has not been studied. Furthermore, few studies on responses to grazers have examined the multiple taxonomic, spatial, and structural components of grassland biodiversity. Recent evidence suggests that biodiversity components strongly influence structural and functional attributes of grassland ecosystems (Archer and Smeins 1991, Tilman and Downing 1994, Frank and McNaughton 1991), yet the factors affecting these different components of biodiversity in rangelands remain poorly understood (West 1993).

Both selective and non-selective grazing or soil disturbance associated with grazer activity can potentially increase or decrease plant species diversity (Huntly 1991). Theoretical models (e.g., Milchunas et al. 1988) predict greater plant species diversity under moderate grazing than under ungrazed conditions in sub-humid grasslands. Furthermore, grazers may interact with other processes operating at different spatial and temporal scales, such as fire, drought, or other species interactions (Coppock and Detling 1986, Grime et al. 1987), resulting in scale-dependent effects. For example, fire-induced spatial and temporal variation in vegetation composition may determine both the pattern of grazing (Coppock and Detling 1986, Vinton et al. 1993) and plant species responses following defoliation (Collins 1987, Pfeiffer and Hartnett 1995).

The objective of this study was to assess the effects of bison grazing on the composition and biodiversity (plant species richness, equitability, and spatial heterogeneity) of tallgrass prairie plant communities in sites of contrasting prescribed fire regimes and topographical positions. Based on theoretical predictions for sub-humid grasslands and greater annual use of recently burned as compared to unburned tallgrass prairie by bison (Vinton et al. 1993), we hypothesized that floristic diversity would be greater under moderate bison grazing than in ungrazed prairie and that this enhancement in floristic diversity would be greater in annually burned than in less frequently burned prairie.

\section{Materials and Methods}

The study was conducted on the Konza Prairie Research Natural Area, a 3,487 ha tallgrass prairie in the northern Flint Hills region of northeastern Kansas $\left(39^{\circ} 05^{\prime} \mathrm{N}, 96^{\circ} 35^{\prime} \mathrm{W}\right)$. Average monthly temperature ranges from a January low of $-2.7^{\circ} \mathrm{C}$ to a July high of $26.6^{\circ} \mathrm{C}$. Average annual total precipitation is 835 $\mathrm{mm}$ with $75 \%$ falling during the growing season (Bark 1987). 
The Flint Hills region encompasses over 1.6 million ha extending throughout much of eastern Kansas from near the KansasNebraska border south into northeastern Oklahoma, and contains the largest remaining areas of unplowed tallgrass prairie in North America.

The vegetation of Konza Prairie is dominated by warm-season perennial grasses, i.e., big bluestem (Andropogon gerardii Vit.), indiangrass (Sorghastrum nutans [L]. Nash), little bluestem (Schizachyrium scoparium [Michx.] Nash-Andropogon scoparius Michx.), switchgrass (Panicum virgatum L.), with numerous subdominant $\mathrm{C}_{3}$ and $\mathrm{C}_{4}$ grasses, composites, legumes, and other forbs (Kuchler 1967, Freeman and Hulbert 1985). A few woody species such as leadplant (Amorpha canescens Pursh), buckbrush (Symphoricarpos orbiculatus Moench.), New Jersey tea (Ceanothus herbaceous Raf.), and smooth sumac (Rhus glabra L.) are locally common. The vascular flora of Konza includes over 500 species representing over 60 families (Freeman and Hulbert 1985). The residual soils are Chase silt loams and silty clay loams derived from Permian limestones, shales, and cherty limestones (Clayey-skeletal, montmorillonitic, mesic, Udic Arguistolls, and Fine mixed, mesic, Pachic Arguistolls). American bison (Bison bison) were the dominant large native herbivore in this region until European settlers established cattle grazing as the primary land use in the latter half of the nineteenth century.

Fifty bison were stocked in a 469-ha portion of Konza Prairie in 1987 at 9 ha $\mathrm{AU}^{-1}$. The stocking rate gradually increased to 5 ha $\mathrm{AU}^{-1}$ by 1992 through natural herd growth. The area grazed by bison was expanded to include an additional 480 ha in May 1992. The animals are free to move among 10 watersheds (avg. size $=$ $100 \mathrm{ha}$ ) that are subjected to prescribed burning in April at 1-yr, 2-year, 4-year, or 20-year intervals. Before 1987, the watersheds had not been grazed since the late 1960's and had been subjected to their prescribed burning intervals since the mid-1970's. Before the bison re-introduction in 1987,8 permanent $5 \mathrm{~m} \times 5 \mathrm{~m}$ exclosures were erected at different sites within each of the grazed watersheds. The exclosures were randomly located but stratified between upland (shallow Florence cherty silt loam) and lowland (Tully silt clay loam) topographical positions.

For this study, we sampled grazed and ungrazed vegetation at 6 exclosure sites in an annually bumed watershed and 6 sites in a watershed burned at 4-year intervals. The sites were sampled 3 times during the 1991 growing season (early June, mid-July, and late September), the fourth year following stocking with bison. Thus, our sampling assessed the cumulative effects of 4 years of absence or presence of bison grazing. Sampling at 3 times throughout the season was necessary because the plant species vary in their growth and flowering phenology and a single sampling would introduce significant bias in abundance estimates against those species not growing actively during the sampling period.

At each of the 6 replicate sites, vegetation was sampled within the $5 \mathrm{~m} \times 5 \mathrm{~m}$ permanent exclosure and along a nearby randomly placed transect within the surrounding grazed vegetation. Four 1$\mathrm{m}^{2}$ quadrats were located within each exclosure and along each nearby transect. Within each quadrat, the cover and frequency of each plant species was estimated using a modified point-frame method (Cook and Stubbendieck 1986). A 10-pin frame was placed systematically at 4 locations (each $25 \mathrm{~cm}$ apart) within each $1 \mathrm{~m}^{2}$ quadrat ( 4 frames $=40$ pins per $\mathrm{m}^{2}$ quadrat). From the pin-contact data, the relative cover (total number of pin-contacts made by individuals of species $x$ /total number of pin-contacts of all species) was calculated for each plant species, and the maximum species cover value attained among the 3 sample dates was retained for analyses. Canopy cover reflects effects of current herbivory on each species in the plant community. Species frequency is much less sensitive to year-to-year climatic variability and current grazing, and thus is a better integrated measure of changes in species composition over time. Thus, frequency (percentage of 10-pin-frames in which species $x$ was encountered) was estimated for each plant species in addition to its cover and both were used in the analyses. Both the stratified random placement of exclosures and pre-treatment vegetation sampling within each site conducted in 1986 (Konza LTER program data set PVC02, unpublished) confirmed no initial differences in vegetation composition between exclosures and nearby grazed transects within each watershed.

The 6 sites were the experimental sampling units in this study. The experimental design included 6 replicate grazed transects and ungrazed exclosures within each large watershed, but no replication of the annually burned or 4-year burned watersheds. At each site, the sampling (number of pin frames and their spacing) was the same for each exclosure and its adjacent grazed area. Some species occurred at only upland or only lowland topographical positions within each watershed. Thus, differences in the abundance of each plant species between grazed and ungrazed sites were analyzed via a separate one-way ANOVA for each topographical position within each watershed.

Plant species richness $(S=$ number of species encountered per unit area) and evenness or equitability of species' relative abundances $\left(E=H^{\prime} / \mathrm{InS}\right)$ were calculated for grazed and ungrazed sites in each watershed. Species diversity, which includes both richnesss and evenness components, was calculated for grazed and ungrazed sites using the Shannon index $\left(\mathrm{H}^{\prime}=-\sum p_{\mathrm{i}} \bullet \operatorname{In} p_{\mathrm{i}}\right)$, where $p_{\mathrm{i}}=$ relative frequency [or cover] of species $i$ (Magurran 1988). Spatial diversity (heterogeneity) of the plant community was calculated for each grazed and ungrazed site following the method of Collins (1992) as the mean \% dissimilarity in species composition for all pairwise comparisons of $1 \mathrm{~m}^{2}$ quadrats at each sampling site within each watershed. Percent dissimilarity was defined as 1 - Czeckanowski's similarity index $\left[2 \Sigma \min \left(x_{\mathrm{ij}}\right.\right.$, $\left.\left.\mathrm{x}_{\mathrm{ik}}\right) / \Sigma\left(\mathrm{x}_{\mathrm{ij}}=\mathrm{x}_{\mathrm{ik}}\right)\right]$, where $\mathrm{x}_{\mathrm{ij}}$ and $\mathrm{x}_{\mathrm{ik}}$ are the frequencies of species $i$ in quadrats $j$ and $k$ respectively (Collins, 1992). Rank transformations of these diversity components were analyzed using ANOVA (Conover and Iman 1981), with grazing as the main factor and topographic position as a blocking factor. Statistical differences in $\mathrm{S}, E, \mathrm{H}^{\prime}$ and heterogeneity between grazed sites ( $\mathrm{n}=$ 6) and exclosures $(n=6)$ within each watershed were further assessed with a Mann-Whitney U-test (Sokal and Rohlf, 1981).

\section{Results}

Differential plant species responses to bison grazing were clearly evident at all sample sites (Fig. 1). Several species were more frequent on grazed transects, some showed higher frequency in ungrazed exclosures, some showed no response, and others varied in their responses between topographical positions and fire regimes (Fig. 1, Tables 1 and 2). Among the dominant rhizomatous grasses, the frequency of big bluestem did not differ among treatments, whereas the frequencies of indiangrass and switchgrass were greater in ungrazed then grazed sites (Fig. 1). The cover of big bluestem, indiangrass, switchgrass, and rough 


\section{Annually Burned Uplands}

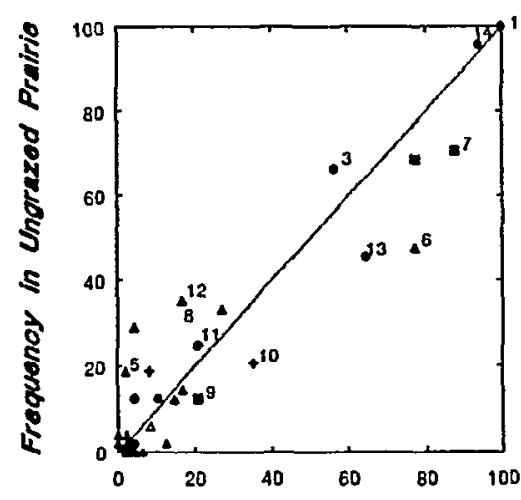

Froquency in Grazed Prairie

\section{Annually Burned Lowlands}

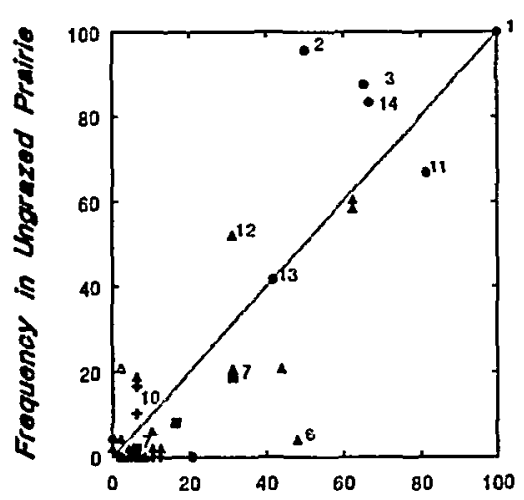

Froquency in Grazed Prairio 4-year Burned Uplanas

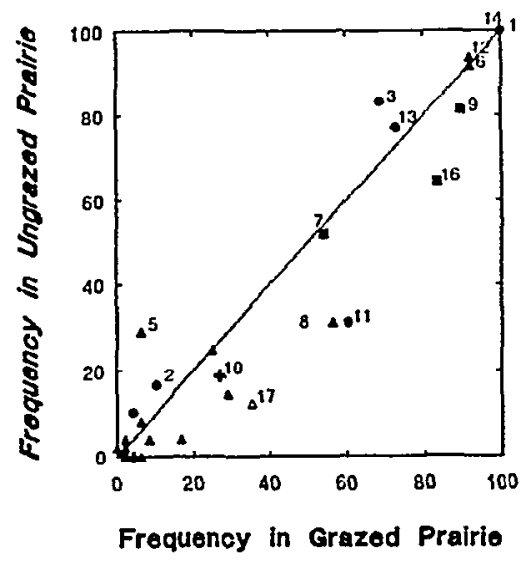

4-year Burned Lowlands

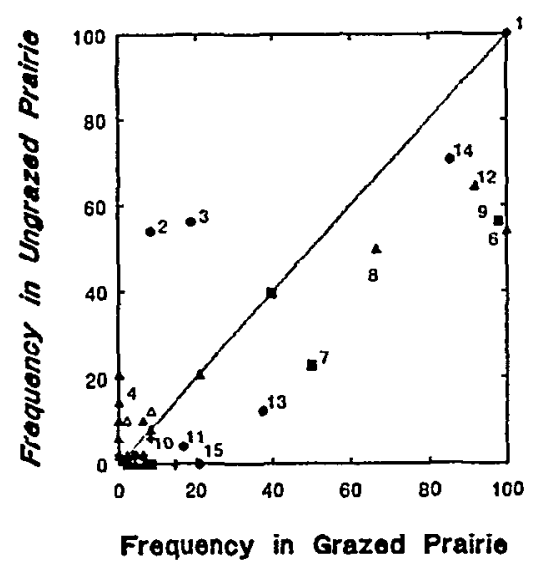

Fig. 1. Mean frequency $(\%)$ of plant species in grazed and ungrazed sites in upland and lowland topographical positions in annually burned and 4-year burned prairie. Each data point represents a species. $\square=C_{3}$ annual grass. $\square=C_{3}$ perennial grass. $O=C_{4}$ annual grass. $\bullet=C_{4}$ perennial grass. $\Delta=$ annual forb. $\Delta$ perennial forb. $t=$ shrub. Selected species numbered on the figure include: $1=$ big bluestem (Andropogon gerardii), 2 = switchgrass (Panicum virgatum), 3 =Indiangrass (Sorghastrum nutans), $4=$ whorled milkweed (Asclepias verticillata), $\mathbf{5}=$ prairie goldenrod (Solidago missouriensis), $6=$ white aster (Aster ericoides), $7=$ sedges (Carex spp.), $8=$ white sage (Artemisia ludoviciana), 9 = Kentucky bluegrass (Poa pratensis), 10 = leadplant (Amorpha canescens), 11 = sideoats grama (Bouteloua curtipendula), 12 = western ragweed (Ambrosia psilostachya), 13 = little bluestem (Schizachyrium scoparium), $14=$ rough dropseed (Sporobolus asper), 15 = western wheatgrass (Agropyron smithii), $16=$ Scribner's dichanthelium (Dichanthelium oligosanthes var, scribneranium). $17=$ yellow wood sorrel (Oxalis stricta).

dropseed (Sporobolus asper [Michx.] Kunth) decreased consistently in response to bison grazing (Tables 1 and 2). However, in the annually burned watershed this negative effect of bison on the cover of tallgrass species was greater in upland sites for most species (Table 1), whereas in the 4-year burned watershed effects of bison were greater in the lowland sites for most species (Table 2). The bunchgrass little bluestem showed a significant response to bison only in the 4-year burned lowland sites where its cover and frequency were greater in grazed sites (Table 2, Fig. 1). The mid-grass sideoats grama and the cool season graminoids Kentucky bluegrass and western wheatgrass, increased in cover and frequency in response to bison, and more significantly in the 4-year bumed watershed than in the annually burned watershed (Tables 1 and 2, Fig. 1). Forb species that showed increased cover in response to bison included leadplant, white aster (Aster ericoides L.), western ragweed (Ambrosia psilostachya DC.), yellow wood sorrel (Oxalis stricta L.), fringeleaf ruellia (Ruellia humilis Nutt.), and prairie ground cherry (Physalis pumila Nutt.). Leadplant, white aster, and yellow wood sorrel also showed greater frequency in grazed sites than in ungrazed sites (Fig. 1). For many of these forbs, the magnitude and statistical significance of thu increase in cover in grazed areas differed between the 2 fire regimes (Tables 1 and 2). The only forb that decreased in cover and frequency in response to bison was prairie goldenrod (Solidago missouriensis Nutt.) on upland prairie sites (Table 1, Fig. 1). Canada goldenrod (Solidago canadensis L.) showed a similar trend in lowland sites but its abundance was too variable to detect an effect of bison grazing. Responses of several other grass and forb species to grazing were significant, but their patterns differed depending upon topographic position.

The analysis of variance of each of the plant diversity components $\left(\mathrm{S}, E, \mathrm{H}^{\prime}\right)$ revealed a significant main effect of grazing $(\mathrm{p} \leq 0.05)$ and a significant grazing $X$ topography interaction $(\mathrm{p} \leq 0.05)$. Thus, the means for diversity components in grazed versus ungrazed sites are 
Table 1. Canopy cover (mean + 1SE) of plant species on upland tallgrass prairie sites. Probability values shown are for comparison of grazed versus ungrazed quadrats.

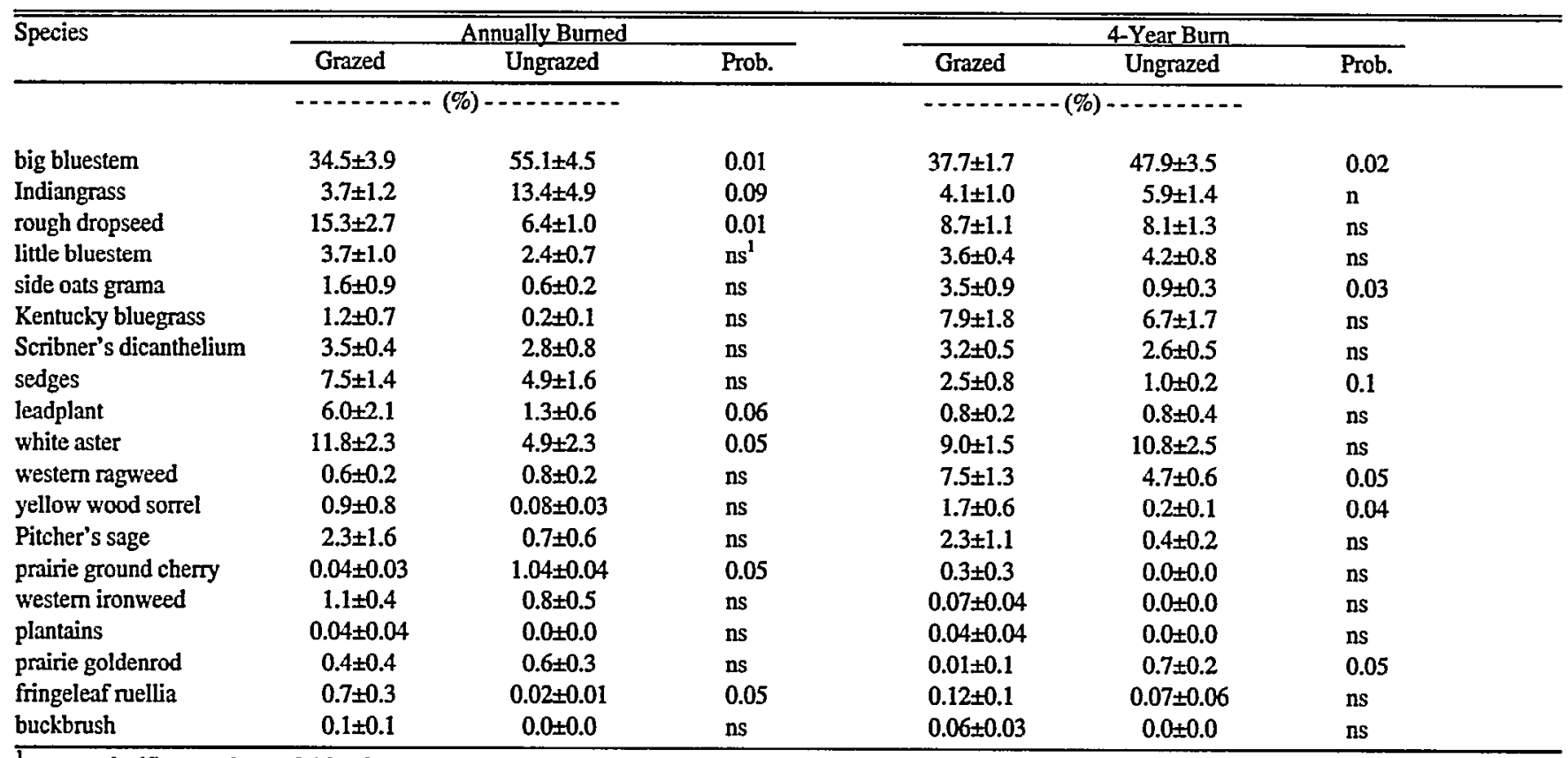

ns $=$ not significant at the $\mathrm{p} \leq 0.1$ level.

reported for lowland and upland topographical positions separately (Table 3). In both the annually burned and 4-year burn watersheds, mean plant species diversity $\left(\mathrm{H}^{\prime}\right)$ was consistently higher $(\mathrm{p} \leq 0.05)$ in grazed areas relative to nearby exclosures. Mean plant species richness also was higher $(\mathrm{p} \leq 0.05)$ for grazed sites ( 38 species per transect) than for ungrazed areas (28 species per exclosure). The increase in species richness associated with bison was generally greater in the annually burned watershed, and greatest in the lowland sites (54\% increase). The smallest increase in floristic diversity due to bison grazing occurred in the upland sampling sites in the 4year burn watershed (19\% increase). The evenness of species abundances was greater $(p \leq 0.05)$ in grazed relative to ungrazed prairie in all except lowland sites in the annually burned watershed (Table 3). These differences in species richness, evenness, and $\mathrm{H}^{\prime}$ between grazed and ungrazed sites are evident in the species, relative abundance distributions (Fig. 2). In all sites, the relative abundance distributions indicated strong dominance by a few species (with big bluestem the most dominant in all sites) and a significant number of rare and sub-dominant species. In all sites studied, the abundancerank curves indicate reduced abundance of the dominant species (greater evenness) and increased species richness in grazed prairie compared to ungrazed areas, but the general shape of the distributions did not vary visually (Fig. 2).

Spatial diversity (community heterogeneity) was significantly greater in grazed sites of both the annually burned and 4-year burned watershed than in ungrazed sites, with the exception that there was no significant effect of bison on heterogeneity in the lowland sites in the 4-year burn watershed (Table 3). The highest

Table 2. Canopy cover (mean \pm 1SE) of plant species on lowland tallgrass prairie sites. Probability values shown are for comparison of grazed versus ungrazed quadrats.

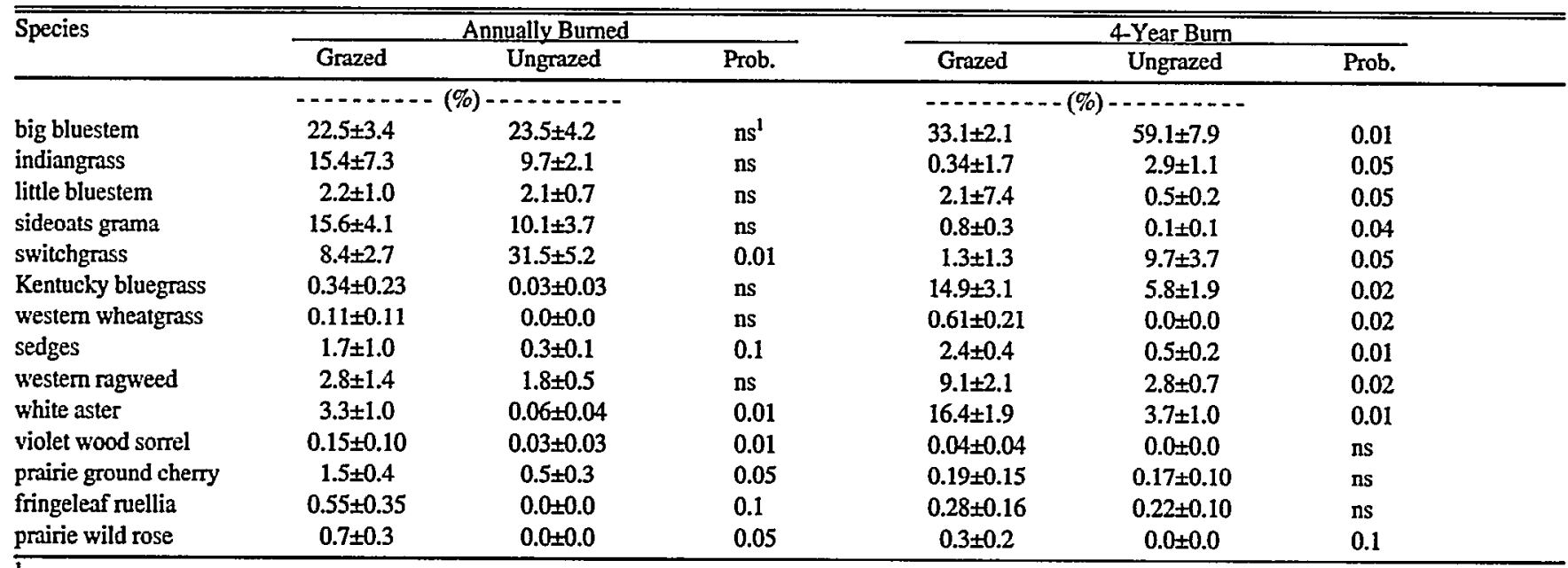

$i_{n S}=$ not significant at the $\mathrm{p} \leq 0.1$ level. 

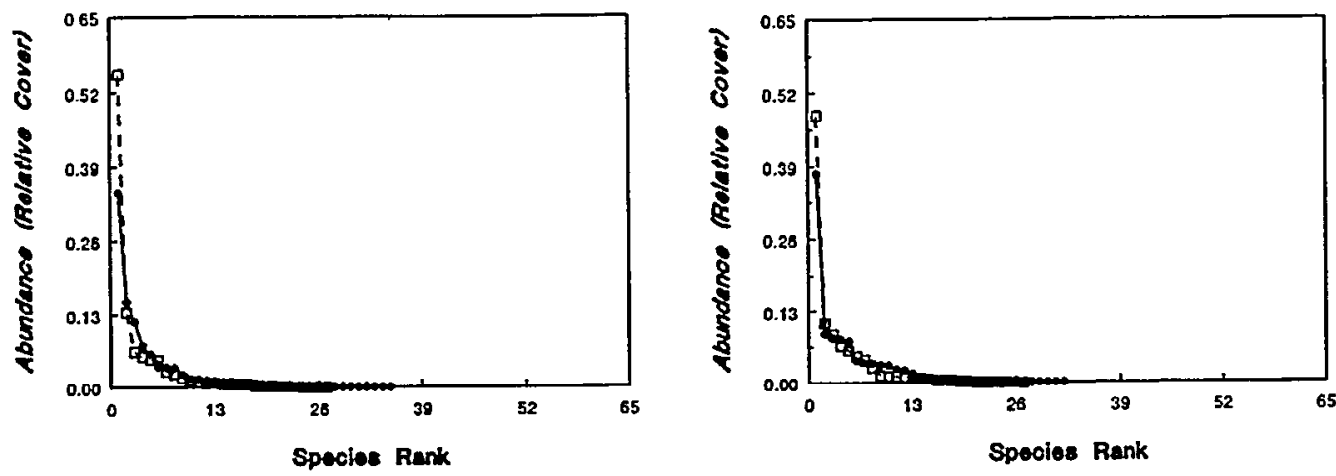

Annually Burned Lowlands

4-year Burned Lowlands
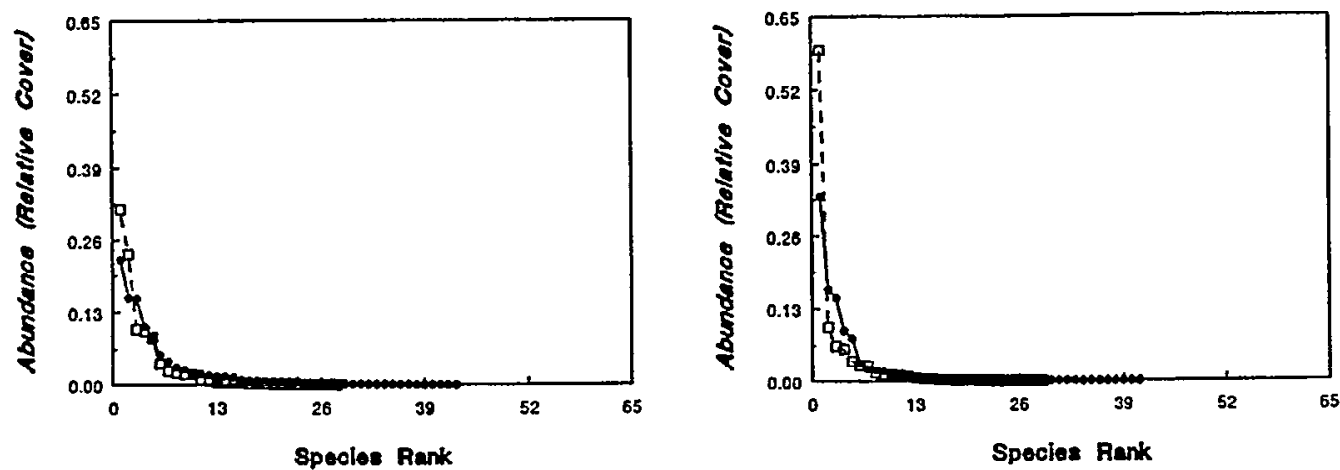

Fig. 2. Rank-abundance diagrams for plant communities in annually burned and 4-year burned tallgrass prairie. Open symbols = grazed by bison. Closed symbols $=$ ungrazed sites.

community heterogeneity $(0.82)$ occurred in the grazed sites of the annually burned watershed, whereas the minimum heterogeneity $(0.40)$ was measured in ungrazed lowland sites in the 4 year burn watershed.

Increased species richness associated with bison grazing was greater with increasing sample area (Fig. 3). A similar pattern in species-area relationships was evident in the annually burned and 4-year burn watersheds; however, the effects of bison on cumulative species richness at larger spatial scales were generally greater in the annually burned watershed (Fig. 3).

\section{Discussion}

Consistent differential plant species responses to bison grazing occurred in both the annually burned and 4-year burn prairie. The dominant perennial tallgrasses were reduced in abundance in the grazed sites, whereas several of the shorter-statured subordinate grasses, sedges, and some forbs showed greater relative abundance in grazed sites. The changes in species abundances observed here in response to bison were consistent with "increaser", "decreaser", and "invader" species responses to livestock.

Table 3. Plant diversity components in tallgrass prairie sites. Grazed $=$ sites grazed year-round by bison. Ungr. $=$ ungrazed sites. $S=$ species richness (mean number of species per sampling site). $E=$ evenness index $\left.=H^{\prime} / H^{\prime} \max =H^{\prime} / I n S\right) H^{\prime}=$ Shannon species diversity index $\left(H^{\prime}=-\Sigma p_{i}\right.$. In $p_{j}$, where $\mathbf{p}_{\mathbf{i}}=$ the relative cover of species $\left.i\right)$. Heterogeneity $=$ spatial diversity $=$ mean percent dissimilarity in specles composition among plots within a site (see text for details).

\begin{tabular}{|c|c|c|c|c|c|c|c|c|}
\hline & \multicolumn{2}{|c|}{$S$} & \multicolumn{2}{|c|}{$E$} & \multicolumn{2}{|c|}{$\mathbf{H}$} & \multicolumn{2}{|c|}{ Heterogeneity } \\
\hline & Ungr. & Grazed & Ungr. & Grazed & Ungr. & Grazed & Ungt. & Grazed \\
\hline $\begin{array}{l}\text { Annually burned prairie } \\
\text { upland sites }\end{array}$ & 27 & 35 & 0.42 & $0.53^{*}$ & 1.40 & $1.87 *$ & 0.41 & 0.44 \\
\hline $\begin{array}{l}\text { 4-year bum prairie } \\
\text { upland sites } \\
\text { lowland sites }\end{array}$ & $\begin{array}{l}27 \\
29\end{array}$ & $\begin{array}{l}32^{*} \\
41^{*}\end{array}$ & $\begin{array}{l}0.53 \\
0.38\end{array}$ & $\begin{array}{l}0.59 * \\
0.50\end{array}$ & $\begin{array}{l}1.76 \\
1.29\end{array}$ & $\begin{array}{l}2.03^{*} \\
1.85\end{array}$ & $\begin{array}{l}0.33 \\
0.40\end{array}$ & $\begin{array}{l}0.38 * \\
0.39\end{array}$ \\
\hline
\end{tabular}

* = significantly different from ungrazed siles at the $\mathrm{p} \leq 0.05$ level (Mann Whitney $\mathrm{U}$ test). 
4-year Burn

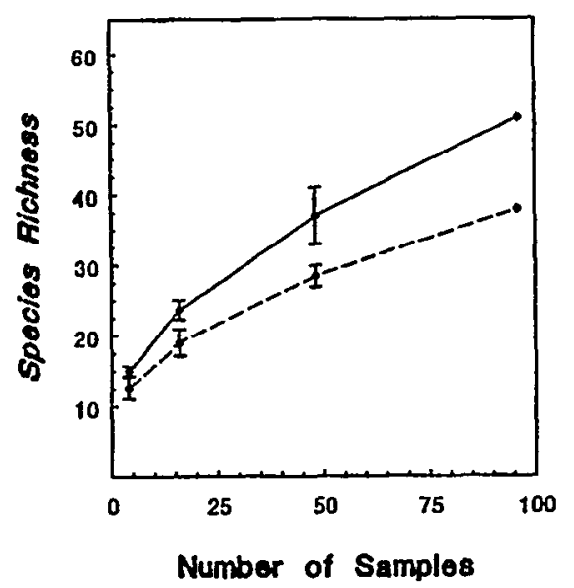

Annually Burned

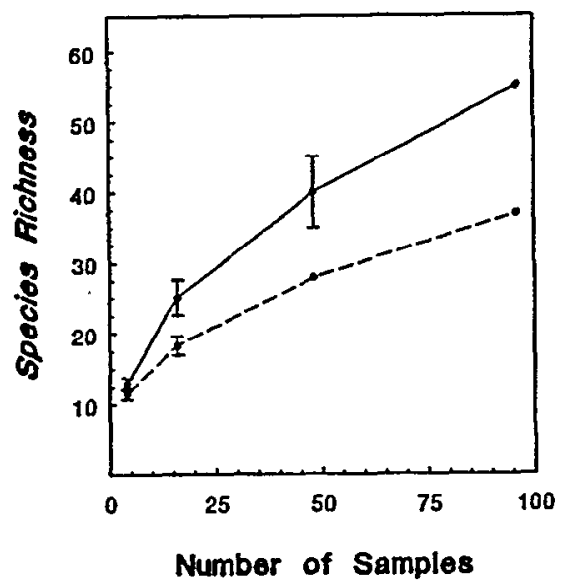

Fig. 3. Species-area relationships for plant communities on annually burned and 4-year burned watersheds on the Konza Prairie Research Natural Area. Open symbols and dashed lines = ungrazed sites (exclosures). Closed symbols and solid lines = sites grazed by bison. Vertical bars $= \pm 1$ SE.

grazing in tallgrass prairie (Dyksterhuis 1958, Voigt and Weaver 1951, Weaver and Hanson 1941, Weaver 1968). These workers interpreted these changes as resulting from preferential grazing of the palatable dominant grasses and decrease in their cover, concomitant competitive release and increased abundance of unpalatable subordinate species, and eventual colonization by ruderal species with prolonged or severe grazing (Weaver 1968). In the present study, however, many species could not easily be separated into these distinct classes, because their response to bison grazing differed between watersheds and topographical position. For example, little bluestem, classified as a decreaser under livestock grazing, showed increased abundance with bison grazing in the 4-year burn watershed, and no significant response to bison in the annually burned prairie. This response is consistent with recent studies on Konza Prairie that showed that bison avoid grazing little bluestem relative to neighboring warm-season tallgrasses in unburned prairie, but that they grazed it in equal frequency to these neighboring grasses in burned prairie (Pfeiffer and Hartnett 1995). Also, the patterns of species responses to bison grazing are influenced by the ways in which the abundance data were collected. For many species, estimation of both canopy cover and frequency indicated similar effects of bison on changes in abundance. For a few species, however, significant differences in cover but not frequency between grazed and ungrazed sites indicate an effect of current year's level of herbivory on the aboveground canopy but no significant longer-term population change. Because frequency estimates were based on occurrence of a species contact with the pin frame rather than rooted plant frequency, they may also be influenced by effects of current year's herbivory on plant size. However, sampling was done on multiple dates beginning early in the growth period of the dominant grasses and, for each species, the maximum relative frequency value for the 3 sampling dates was used in the analyses. Thus, any potential influence of current year's herbivory on species frequencies was minimized.

The net effect of these differential plant species responses was a significant increase in several components of plant diversity on sites grazed by bison over the 4-year period. In both watersheds, plant species richness, evenness, species diversity, and spatial diversity (heterogeneity) were higher in grazed compared to ungrazed areas. Greater plant species diversity on sites moderately grazed by bison relative to ungrazed sites supports specific predictions of the intermediate disturbance hypothesis and the generalized model of Milchunas et al. (1988) for grasslands. In the absence of grazing, a few tallgrass species dominate the community, whereas moderate grazing results in a more species rich mosiac pattern of shortgrasses, tallgrasses, and forbs and a mosaic pattern of canopy structure (Milchunas et al. 1988). These models make further predictions concerning the form of relationship between grazing intensity and plant species diversity, however, our study included only a pairwise moderately grazed/ungrazed comparison and was unable to test these specific relationships for tallgrass prairie.

Studies in different grasslands have documented significant effects of large grazers on plant species diversity (Cid et al. 1991, Dyer et al. 1982, Heady 1967, Noy-Meir et al. 1989, Whicker and Detling 1988). In a short-term experiment in Oklahoma tallgrass prairie, Collins (1987) found higher plant species diversity in sites grazed seasonally by cattle, and a significant interaction between grazing and fire effects on species diversity. In contrast, (Kucera 1956) found decreased plant species diversity in Missouri tallgrass prairie sites that were grazed intensively for many years, and a significant drought-grazing interaction affecting trends in plant community composition. Smart et al. (1985) showed that long-term exclusion of grazers from east African grasslands resulted in a floristically poor plant community heavily dominated by just 2 grasss species.

Although lack of replication of annually burned and 4-year burn watersheds precluded statistical examination of fire $X$ bison grazing interactions in our study, consistent patterns among replicate sites in each watershed suggest that plant community responses to bison are influenced by fire frequency. Bison caused greater increases in species richness and heterogeneity in the annually burned watershed than they did in the 4-year burn 
watershed. This is likely the result of the greater use of annually burned sites by bison on Konza Prairie (Vinton et al., 1993), and relatively larger shifts in the competitive balance between the dominant grasses and subordinant species in annually burned prairie where, in the absence of grazing, the tallgrasses typically exert stronger competitive effects.

Herbivores can influence the composition and diversity of plant communities via a variety of mechanisms (Huntly 1991). The species' relative-abundance distributions indicated that bison increase both the evenness and richness components of plant species diversity, however, similar shapes of the distributions in grazed versus ungrazed sites suggests that moderate bison grazing does not significantly alter the fundamental processes organizing tallgrass prairie plant communities. The increase in species evenness or equitability is a result of the preferential grazing and reduced dominance of big bluestem, resulting in an increase in the relative abundances of several subordinate species that receive little grazing pressure and experience competitive release from the effects of big bluestem (Fahnestock and Knapp 1993). The increase in species richness and spatial diversity components is likely due to the generation of greater habitat heterogeneity. The mosaic of habitat patches generated by bison grazing and non-grazing activities likely increase the diversity of colonization and establishment opportunities for several species that are otherwise excluded from the community by the strong competitive dominance of the matrix grasses.

Native ungulate grazers and cattle may differ in their effects on tallgrass prairie vegetation composition and biodiversity. Although both bison and cattle display generalist food habits, bison select almost exclusively graminoids (Krueger 1986, Peden et al. 1974, Plumb and Dodd 1993, Schwartz and Ellis 1981) and thus may reduce dominance by matrix grasses and increase species equitability to a greater degree than cattle. Furthermore, bison display other behaviors such as wallowing, they are capable of grazing nearer to the ground than cattle, and their spatial and temporal patterns of grazing activity differ from cattle (e.g. Reinhardt 1985, Polley and Collins 1984). Thus, bison may differ from cattle in their effects on plant species richness and spatial heterogeneity components of grassland biodiversity.

Differences in management may also contribute to differences in vegetation responses to cattle and bison. In tallgrass prairie managed for livestock production, grazing is often seasonal, whereas systems managed with native ungulates such as the Konza Prairie typically involve year-round grazing with minimal grazing management. Thus the temporal and spatial patterns of defoliation may differ considerably. For example, the lack of significant increase in the abundance of cool-season $C_{3}$ grasses observed in this study compared to their increase under cattle grazing is likely due to greater cumulative grazing pressure $C_{3}$ grasses experience under year-round compared to seasonal grazing. Also, many practices employed in the management of domestic cattle on tallgrass prairie, such as intensive-early stocking or other high intensity-short duration grazing systems are designed partially to reduce spatial heterogeneity in grazing intensity, which will affect vegetation spatial diversity. Collins (1987) showed that seasonal cattle grazing at moderate stocking rates increased local plant species richness by 2 to $15 \%$ in Oklahoma tallgrass prairie. In our study, moderate year-long bison grazing increased local plant species richness by 19 to $54 \%$. This further suggests that native and domestic grazers managed in different ways may differ significantly in their influence on tallgrass prairie plant community structure and biodiversity.

Results of this study clearly indicate that bison grazing increases various components of floristic and spatial diversity in tallgrass prairie. Increasing empirical evidence indicates that increased floristic diversity confers greater ecological stability in grasslands, including greater year-to-year stability in the net primary productivity and species composition in response to drought or other stresses (Frank and McNaughton 1991, Tilman and Downing 1994). Thus, effects of native and domestic ungulate grazers on components of grassland biodiversity have important potential implications for grassland ecosystems and range management.

\section{Literature Cited}

Archer, S. and F.E. Smeins. 1991. Ecosystem-level processes. p. 109140. In: R.K. Heitschmidt and J.W. Stuth (eds.) Grazing Management: An Ecological Perspective. Timber Press, Portland, Ore.

Axelrod, D.I. 1985. Rise of the grassland biome, central North America. Bot. Rev. 51:163-201.

Bark, D. 1987. Konza Prairie Research Natural Area, Kansas. In: D. Greenland (ed.). The Climates of the Long-Term Ecological Research Sites. Occasional Paper no. 44, Institute for Arctic and Alpine Research, University of Colorado, pp 45-50.

Cid, M.S., J.K. Detling, A.D. Whicker, and M.A. Brizuela. 1991. Vegetational responses of a mixed-grass prairie site following exclusion of prairie dogs and bison. J. Range Manage. 44:100-105.

Collins, S.L. 1987. Interaction of disturbances in tallgrass prairie: a field experiment. Ecol. 68:1243-1250.

Collins, S.L. 1992. Fire frequency and community heterogeneity in tallgrass prairie vegetation. Ecol. 73:2001-2006.

Collins, S.L. and L.L. Wallace. 1990. Fire in North American Tallgrass Prairies. Univ. Oklahoma Press, Norman, Okla.

Conover, W.J. and R.L. Iman. 1981. Rank transformations as a bridge between parametric and non-parametric statistics. Amer. Stat. 35:124129.

Cook, C.W. and J. Stubbendieck. 1986. Range Research: Basic Problems and Techniques. Society for Range Management, Denver, Colo.

Coppock, D.L. and J.K. Detling. 1986. Alteration of bison and blacktailed prairie dog grazing interaction by prescribed burning. J. Wildlife Manage. 50:452-455.

Dyer, M.I., J.K. Detling, D.C. Coleman, and D.W. Hilbert. 1982. The role of herbivores in grasslands. p. 255-295. In: J.R. Estes, R.J. Tyrl, and J.N. Brunken (eds.). Grasses and Grasslands: Systematics and Ecology. Univ, Oklahoma Press, Norman, Okla.

Dyksterhuis, E.J. 1958. Ecological principles in range evaluation. Bot. Rev. 24:253-272.

Fahnestock, J.T. and A.K. Knapp. 1993. Water relations and growth of tallgrass prairie forbs in response to selective herbivory by bison. Inter. J. Plant Sci. 154:432-440.

Frank, D.A. and S.J. McNaughton. 1991. Stability increases with diversity in plant communities: empirical evidence from the 1988 Yellowstone drought. Oikos 62:360-362.

Freeman, C.C. and L.C. Hulbert. 1985. An annotated list of the vascular flora of Konza Prairic Rescarch Natural Arca, Kansas. Trans. Kans. Acad. Sci. 88:84-115.

Gibson, D.J. and L.C. Hulbert. 1987. Effects of fire, topography and year-to-year climatic variation on species composition in tallgrass prairie. Vegetatio 72:175-185.

Grime, J.P., J.M.L. Mackey, S.H. Hiller, and D.J. Read. 1987. Floristic diversity in a model system using experimental microcosms. Nature 328:420-422.

Heady, H.F. 1966. Influence of grazing on the composition of Themeda triandra grassland, east Africa. J. Ecol. 54:705-728.

Herbal, C.H. and K.L. Anderson. 1959. Response of the true prairie vegetation on major Flint Hills range sites to grazing treatment. Ecol. Monogr. 29:171-186. 
Huntly, N. 1991. Herbivores and the dynamics of communities and ecosystems. Ann. Rev. Ecol. Syst. 22:477-503.

Krueger, K. 1986. Feeding relationships among bison, pronghorn and prairie dogs: an experimental analysis. Ecol. 67:760-770.

Kucera, C.L. 1956. Grazing effects on composition of virgin prairie in north-central Missouri. Ecol. 37:389-391.

Kuchler, A.W. 1967. Some geographic features of the Kansas prairie. Trans. Kans. Acad. Sci. 70:388-401.

Magurran, A.E. 1988. Ecological Diversity and Its Measurement. Princeton University Press, Princeton, N.J.

Milchunas, D.G., O.E. Sala, and W.K. Lauenroth. 1988. A generalized model of the effects of grazing by large herbivores on grassland community structure. Amer. Natur. 132:87-105.

Noy-Meir, I., M. Gutman, and Y. Kaplan. 1989. Responses of Mediterranean grassland plants to grazing and protection. J. Ecol. 77:290-310.

Peden, D.G., G.M. VanDyne, R.W. Rice, and R.M. Hansen. 1974. The trophic ecology of Bison bison L. on shortgrass plains. J. Appl. Ecol. 11:489-498.

Pfeiffer, K.E. and D.C. Hartnett. 1995. Bison selectivity and grazing responses of little bluestem in tallgrass prairie. J. Range Manage. 48:26-31.

Plumb, G.E. and J.L. Dodd. 1993. Foraging ecology of bison and cattle on mixed prairie: implications for natural area management. Ecol. Appl. 3:631-643.

Polley, H.W. and S.L. Collins. 1984. Relationships of vegetation and environment in buffalo wallows. Amer. Midl. Natur. 112:178-186.

Reinhardt, V. 1985. Quantitative analysis of wallowing in a confined bison herd. Acta. Theriologica 30:149-156.
Risser, P.G., E.C. Birney, H.D. Blocker, S.W. May, J. Parton, and J.A. Wiens. 1981. The True Prairie Ecosystem. US/IBP Synthesis Series, No. 16, Hutchinson Ross Publishing Co., Stroudsburg, Penn.

Schwartz, C.C. and J.E. Ellis. 1981. Feeding ecology and niche separation in some native and domestic ungulates on the shortgrass prairie. $J$. Appl. Ecol. 18:343-353.

Smart, N.O.E., J.C. Hatton, and D.H.N. Spence. 1985. The effect of long-term exclusion of large herbivores on vegetation in Murchison Falls National Park, Uganda. Biol. Conserv. 33:229-245.

Sokal, R.P. and F.J. Rohlf. 1981. Biometry. 2nd ed. W.H. Freeman and Company, N.Y.

Tilman, D. and J.A. Downing. 1994. Biodiversity and stability in grasslands. Nature 367:363-365.

Vinton, M.A., D.C. Hartnett, E.J. Finck , and J.M. Briggs. 1993. Interactive effects of fire, bison (Bison bison) grazing and plant community composition in tallgrass prairie. Amer. Midl. Natur. 129:10-18.

Voigt, J.W. and J.E. Weaver. 1951. Range condition classes of native midwestem pastures: an ecological analysis. Ecol. Monogr. 21:39-60.

Weaver, J.E. 1968. Prairie Plants and Their Environment. University of Nebraska Press, Lincoln, Nebr.

Weaver, J.E. and W.W. Hansen. 1941. Native midwestern pastures, their origin, composition and degradation. Univ. Nebr. Conserv. Surv. Div. 22:1-93.

West, N.E. 1993. Biodiversity of rangelands. J. Range Manage. 46:2-13.

Whicker, A.D. and J.K. Detling. 1988. Modification of vegetation structure and ecosystem processes by North American grassland mammals. In: M.J.A. Werger, H.J. During, and P.J.M. Van Der Aart (eds.). Plant Form and Vegetation Structure. Academic Publishing, The Hague, The Netherlands.

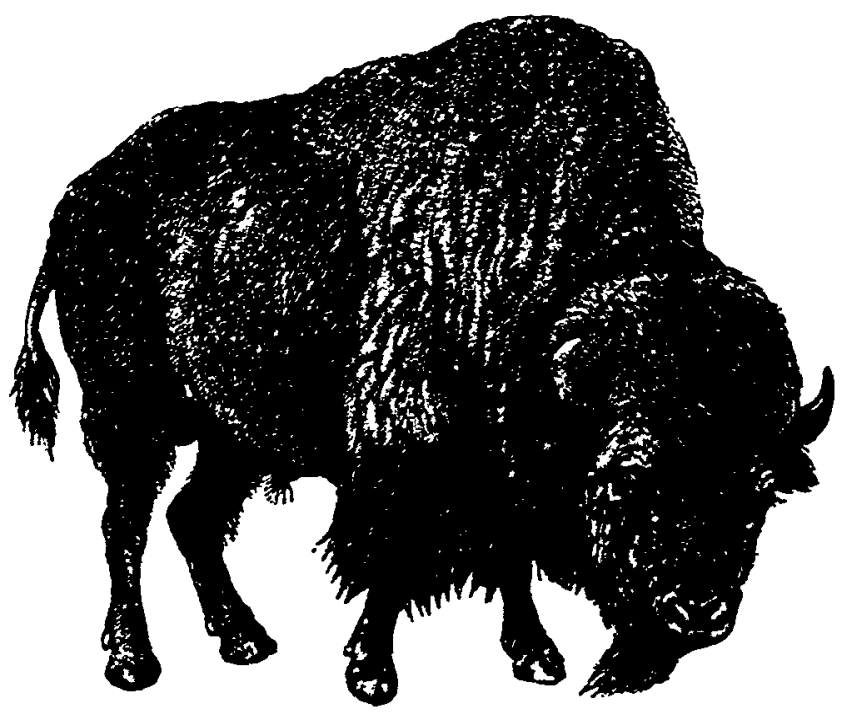

